\title{
A preliminary study of possible fibrotic role of meprin metalloproteases in scleroderma patients
}

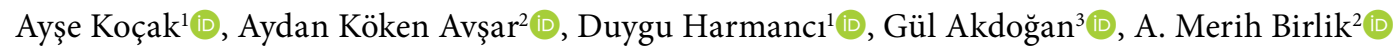 \\ ${ }^{1}$ Department of Molecular Medicine, Dokuz Eylül University Faculty of Medicine, Izmir, Turkey \\ ${ }^{2}$ Department of Internal Medicine, Division of Rheumatology \& Immunology, Dokuz Eylül University Faculty of Medicine, Izmir, Turkey \\ ${ }^{3}$ Department of Medical Biochemistry, Izmir University of Economics, Izmir, Turkey
}

\begin{abstract}
Objectives: This study aims to investigate the possible fibrotic role of meprin metalloproteases and possible fibrotic effects of activator protein-1 (AP-1) in scleroderma patients.

Patients and methods: Between April 2018 and April 2019, a total of 85 scleroderma patients (9 males, 76 females; mean age: $54.9 \pm 12.1$ years; range, 22 to 80 years) who met the 2013 American College of Rheumatology/European League Against Rheumatism criteria and 80 healthy control individuals (10 males, 70 females; mean age $42.9 \pm 10.2$ years; range, 19 to 65 years) were included. Patients' data and blood samples were collected. Messenger ribonucleic acid expressions of interleukin (IL)-6, AP-1 subunits, and tumor necrosis factor-alpha (TNF-a) were analyzed by quantitative real-time polymerase chain reaction. Serum meprin alpha and beta protein levels were analyzed using the enzyme-linked immunosorbent assay.

Results: Meprin alpha and meprin beta protein levels increased in scleroderma patients. The AP-1 subunits (c-Fos, c-Jun), IL-6, and TNF-a increased in scleroderma patients, compared to controls.

Conclusion: Our results provide evidence showing that increased meprins levels may be related to AP- 1 levels and increased meprins levels may responsible for increased inflammatory TNF- $a$ and IL- 6 levels. All these data suggest meprins as promising therapeutic targets to restore the balance between inflammation and extracellular matrix deposition in scleroderma.

Keywords: Activator protein-1, meprin-alpha, meprin-beta, scleroderma.
\end{abstract}

Scleroderma (SSc) is the highest mortality of rheumatological diseases. ${ }^{1}$ Disease pathogenesis is still unclear and different factors including genetic and epigenetic factors, and environmental exposures play a role in the progress of SSc. ${ }^{2,3}$ Fibrosis and extracellular matrix (ECM) dysfunction lead to $\mathrm{SSc}{ }^{3}$ In $\mathrm{SSc}$, the normal tissue process is broken and replace with collagen-rich, stiff connective tissues. ${ }^{4}$ Currently, there are no approved specific therapies for SSc.
Recent studies have not identified molecular targets or pathways.

Options for managing different clinical signs of SSc are currently limited. Few treatments were published in the updated 2017 European League Against Rheumatism (EULAR). ${ }^{5}$ However, there are still unanswered questions regarding $\mathrm{SSc}$ therapeutics.

Meprin metalloproteases (meprin- $\alpha$ and meprin- $\beta$ ) are associated with a pro-inflammatory

Received: November 13, 2020 Accepted: January 31, 2021 Published online: June 24, 2021

Correspondence: Ayşe Koçak, MD. Dokuz Eylül Üniversitesi Moleküler Tıp Anabilim Dalı, 35330 Balçova, İzmir, Türkiye. Tel: +90 507 - 2243706 e-mail: kocak.ayse@gmail.com

\section{Citation:}

Koçak A, Köken Avşar A, Harmancı D, Akdoğan G, Birlik AM. A preliminary study of possible fibrotic role of meprin metalloproteases in scleroderma patients. Arch Rheumatol 2021;36(4):510-517. 
activity, leading to ECM remodeling. Their expressions are upregulated in chronic inflammation, some cancers, and fibrosis. ${ }^{6,7}$ The major physiological function of meprins is the maturation of fibrillar procollagens I and III via cleavage of the $\mathrm{N}$ - and $\mathrm{C}$-terminal pro-domains. ${ }^{8,9}$ Recent studies have shown the anti-inflammatory activity of meprins. ${ }^{6}$ Also, meprin metalloprotease function depends on their localization. The meprin- $\beta$ has a role on the apical side of intestinal epithelial cells and it keeps out of bacterial infection. ${ }^{10}$ Besides, meprin- $\beta$ at the mesenchymal site can induce pro-inflammatory stimuli during the inflammation, such as by cleaving the interleukin (IL)-6 receptor (IL-6R) to induce IL-6 trans-signaling. ${ }^{11}$ Activator protein-1 (AP-1) is a transcription factor that plays a role in cellular proliferation, differentiation, and apoptosis. The AP-1 has two domains that are c-Jun and c-Fos. They regulate fibrosis process and stimulation and responsible for transcriptional regulation of meprin- $\beta .{ }^{7,12}$ Avouac et al. ${ }^{12}$ showed that AP-1 was upregulated in a transforming growth factor (TGF)-dependent manner in SSc. ${ }^{12}$ The tumor necrosis factor alpha (TNF- $\alpha$ ) and IL-6 work together. Also, a disintegrin and metalloprotease 17 (ADAM-17) extracellular region releases IL-6R and TNF- $\alpha$. There are new insights into the potential for cross-talk between the TNF/IL- 6 interaction. ${ }^{13,14}$

Considering the possible fibrotic effects of the meprins and their relation with AP-1 and some inflammatory markers, we aimed to investigate serum protein levels of meprin- $\alpha$ and meprin- $\beta$ and the blood gene expression levels of their regulators in the different types of SSc.

\section{PATIENTS AND METHODS}

This experimental study was conducted at Dokuz Eylül University Faculty of Medicine, Department of Rheumatology and Immunology between April 2018 and April 2019. A total of $85 \mathrm{SSc}$ patients $(9$ males, 76 females; mean age: $54.9 \pm 12.1$ years; range, 22 to 80 years) who met the 2013 American College of Rheumatology (ACR)/EULAR criteria and 80 healthy control individuals (10 males, 70 females; mean age $42.9 \pm 10.2$ years; range, 19 to 65 years) were included. Patients who were unable to understand the rules and implications of the study and pregnant women were excluded from the study. All patients had a standardized physical exam including the modified Rodnan skin score (mRSS) which is a standard measure of SSc by estimating the skin thickness in 17 body areas. The 2015 European Society of Cardiology (ESC) and by the European Respiratory Society (ERS) guidelines and right heart catheterization (RHC) were used to identify pulmonary arterial hypertension (PAH). ${ }^{15} \mathrm{PAH}$ was confirmed by RHC, when the mean pulmonary artery pressure was found to be $\geq 25 \mathrm{mmHg}$ at rest with a mean pulmonary arterial wedge pressure of $\leq 15 \mathrm{mmHg}$. Scleroderma renal crisis (SRC) was defined as new-onset hypertension with a blood pressure of $>150 / 85 \mathrm{mmHg}$ associated with a decrease in renal function or manifestations of malignant hypertension. Joint involvement included arthralgia, synovitis, and/or tendon friction rubs. Gastrointestinal involvement included reflux, dysmotility, constipation, or diarrhea; signs of bacterial overgrowth and/or malabsorption; and abnormal manometry and/or endoscopy test. A written informed consent was obtained from each patient. The study protocol was approved by the Ethics Committee of Dokuz Eylül University Faculty of Medicine (3930-GOA). The study was conducted in accordance with the principles of the Declaration of Helsinki.

\section{SSc classification and symptoms}

Diagnosis and classification of limited cutaneous SSc (lcSSc) and diffuse cutaneous $\mathrm{SSc}(\mathrm{dcSSc})$ were made according to LeRoy et al. $^{16}$ The SSc history, organ involvement (e.g., heart, lung, pulmonary arteries), skin extent, and antibodies were defined by standard criteria. ${ }^{17}$

\section{Blood total ribonucleic acid (RNA) isolation}

The ethylenediaminetetraacetic acidanticoagulated blood samples were collected from each patient. Within $30 \mathrm{~min}$, the plasma was removed and centrifuged at $4{ }^{\circ} \mathrm{C}$ and total RNA isolation was performed using the RNA isolation kit (QIAamp RNA Blood Mini Kit, Qiagen $\mathrm{GmbH}$, Hilden, Germany) and stored at $-20^{\circ} \mathrm{C}$ until analysis. The total amount of RNA obtained was evaluated with a micro-volume spectrophotometer (NanoDrop 2000/2000c Spectrophotometer, Thermo Scientific, Waltham, 
MA, USA) at a wavelength of 260 and $280 \mathrm{~nm}$. If the A260/A280 absorbance ratio was 1.8 to 2.0, it was accepted as pure for RNA.

Detection of IL-6, TNF-a, c-Jun, c-Fos messenger RNA (mRNA) levels by quantitative reverse transcriptase-polymerase chain reaction ( $q R T-P C R$ )

Blood samples were used for the detection of IL-6, TNF- $\alpha$, c-Jun, c-Fos mRNA levels by a qRT-PCR test. First-strand complementary deoxyribonucleic acid (cDNA) was synthesized from $1 \mu \mathrm{g}$ total RNA in $20 \mu \mathrm{L}$ by reverse transcription using a high-capacity cDNA kit (Applied Biosystems, CA, USA) according to the manufacturer's instructions. Reverse transcription reaction consisted of $2 \mu \mathrm{L}$ Oligo-dT $(50 \mu \mathrm{M})$, $2 \mu \mathrm{L}$ of $10 \times$ reverse transcriptase buffer, $0.8 \mu \mathrm{L}$ of deoxynucleoside triphosphate $(25 \mathrm{mM}), 1 \mu \mathrm{L}$ of RNase inhibitor ( $40 \mathrm{U} / \mu \mathrm{L}), 1 \mu \mathrm{L}$ of MultiScribe Reverse Transcriptase $(50 \mathrm{U} / \mu \mathrm{L})$, and RNAse free $\mathrm{dH}_{2} \mathrm{O}$, up to a final volume of $20 \mu \mathrm{L}$. The cDNA was, then, stored at $-20^{\circ} \mathrm{C}$ for the gene expression study. Real-time qRT-PCR was performed to detect the gene expression of IL-6, TNF- $\alpha$, c-Jun, and c-fos in blood using SYBR master mix (Qiagen Inc., CA, USA) at $95^{\circ} \mathrm{C}$ for $10 \mathrm{~min}$, followed by 40 cycles of $95^{\circ} \mathrm{C}$ for $15 \mathrm{sec}$ and $60^{\circ} \mathrm{C}$ for $30 \mathrm{sec}$, and the reaction was performed using the Rotor-Gene $\mathrm{Q}$, (Qiagen Inc., CA, USA) real-time PCR cycler. The glyceraldehyde-3-phosphate dehydrogenase (GAPDH) was used as an internal control. The primers that were used are listed below:

GAPDH: F 5'-GTCTCCTCTGACTTCAACAGCG-3'

R 5'-ACCACCCTGTTGCTGTAGCCAA-3', IL-6: F 5'-AATTCGGTACATCCTCGACGG-3'

R 5'-GGTTGTTTTCTGCCAGTGCC-3'

TNF- $\alpha$ : F 5'-CTCTTCTGCCTGCTGCACTTTG-3'

R 5'-ATGGGCTACAGGCTTGTCACTC-3', c-Jun: F 5'-GAGGAAGCGCATGAGGAA-3'

R 5'-TCCTTTTTCGGCACTTGG-3'

c-Fos: F 5'-ACCTGTCAAGAGCATCAGCA-3'

\section{R 5'CATCAAAGGGCTCGGTCTT-3'}

Relative quantification was performed using the $2 \Delta \Delta \mathrm{Ct}$ method. ${ }^{18,19}$ The experiments were performed in triplicate and were repeated twice.

Meprin- $\alpha$ and meprin- $\beta$ enzyme-linked immunosorbent assay (ELISA) experiments
Meprin- $\alpha$ and Meprin- $\beta$ levels were determined according to manufacturer's instructions using commercial ELISA kits. The following kits were utilized: Human meprin- $\alpha$ subunit/MEP1A and human meprin- $\beta$ subunit/MEP1B (R\&D Systems Inc., MN, USA). Serum samples were assayed in duplicate and compared to a standard curve using a microtiter plate reader (Synergy HT, Multi-Detection Microplate Reader, BIO-TEK, USA). Based on standard curves, meprin- $\alpha$ and $-\beta$ concentrations were determined.

\section{Statistical analysis}

Statistical analysis was performed using the IBM SPSS version 24.0 software (IBM Corp., Armonk, NY, USA). Descriptive data were presented in mean \pm standard deviation (SD), median (min-max) or number, where applicable. The analysis of variance (ANOVA) Sidak's test was performed to compare the groups. Dual comparisons were made using the Mann-Whitney $\mathrm{U}$ test. The Pearson correlation test was used. A $p$ value of $<0.05$ was considered statistically significant.

\section{RESULTS}

Diagnosis and classification of SSc were made according to Schmittgen et al. ${ }^{19}$ Demographic and clinical features of patient and control groups are shown in Table 1 and Figure 1.

The meprin- $\alpha$ and meprin- $\beta$ protein levels were found to increase in the SSc group, compared to the controls $(p<0.05)$ (Figure 2).

The IL-6 gene expression increased in the $\mathrm{SSc}$ group, compared to the control group. Also, the AP-1 (c-Jun \& c-Fos homolog dimers) gene expression increased in the SSc patients, compared to the control group. The TNF- $\alpha$ gene expression increased in the SSc patients, compared to the control group $(p<0.05)$ (Figure 3).

A positive, significant correlation was found between the mRSS and TNF- $\alpha \quad(r=0.459$, $p=0.000)$, meprin- $\alpha \quad(r=0.307, \quad p=0.006)$, c-Jun $(r=0.580, \quad p=0.000)$, and meprin- $\beta$ $(r=0.499, p=0.000)$ (Figure 4). However, there was no significant correlation between the c-Fos and mRSS. 
Table 1. Demographic and clinical characteristics of study population

\begin{tabular}{|c|c|c|c|c|}
\hline & \multicolumn{2}{|c|}{ Patients Group ( $\mathrm{n}=85$ ) } & \multicolumn{2}{|c|}{ Control Group $(n=80)$} \\
\hline & $\mathrm{n}$ & Mean \pm SD & $\mathrm{n}$ & Mean \pm SD \\
\hline Age (year) & & $54.9 \pm 12.1$ & & $42.9 \pm 10.2$ \\
\hline \multicolumn{5}{|l|}{ Sex } \\
\hline Female & 76 & & 70 & \\
\hline Male & 9 & & 10 & \\
\hline Diffuse type/limited type & $32 / 53$ & & & \\
\hline Disease duration (year) & & $11 \pm 7.4$ & & - \\
\hline Onset Raynaud (year) & & $6.2 \pm 4.1$ & & - \\
\hline Onset first non-Raynaud (year) & & $4.2 \pm 2.5$ & & - \\
\hline mRSS & & $7.0 \pm 1.0$ & & - \\
\hline \multicolumn{5}{|l|}{ Digital ulcers (past or active) } \\
\hline Yes & 32 & & - & \\
\hline No & 53 & & - & \\
\hline \multicolumn{5}{|l|}{ Calcinosis } \\
\hline Yes & 9 & & - & \\
\hline No & 76 & & - & \\
\hline \multicolumn{5}{|l|}{ Joint involvement } \\
\hline Yes & 33 & & - & \\
\hline No & 52 & & - & \\
\hline \multicolumn{5}{|l|}{$\mathrm{PAH}$} \\
\hline Yes & 5 & & - & \\
\hline No & 80 & & - & \\
\hline \multicolumn{5}{|l|}{ ILD } \\
\hline Yes & 40 & & - & \\
\hline No & 45 & & - & \\
\hline \multicolumn{5}{|l|}{ GIS involvement } \\
\hline Yes & 7 & & - & \\
\hline No & 78 & & - & \\
\hline \multicolumn{5}{|l|}{ SRC } \\
\hline Yes & 2 & & - & \\
\hline No & 83 & & - & \\
\hline \multicolumn{5}{|l|}{ ANA positive } \\
\hline Yes & 80 & & - & \\
\hline No & 5 & & - & \\
\hline \multicolumn{5}{|l|}{ ACA positive } \\
\hline Yes & 48 & & - & \\
\hline No & 37 & & - & \\
\hline
\end{tabular}

mRSS: Modified Rodnan skin score; PAH: Pulmonary arterial hypertension; ILD: Interstitial lung disease; GIS: Gastrointestinal; SRC: Scleroderma renal crisis; ANA: Antinuclear antibody; ACA: Anti-centromeric antibody.

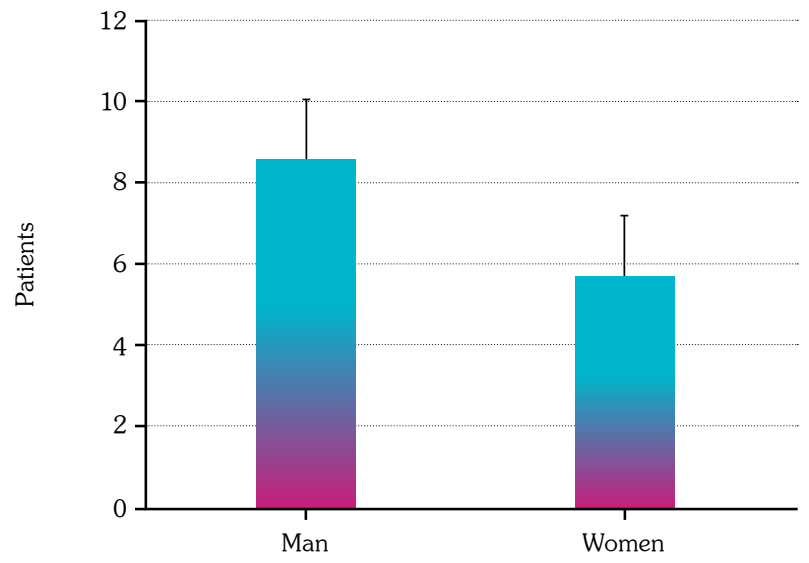

Figure 1. Disease score in man and woman with SSc. 
(a)

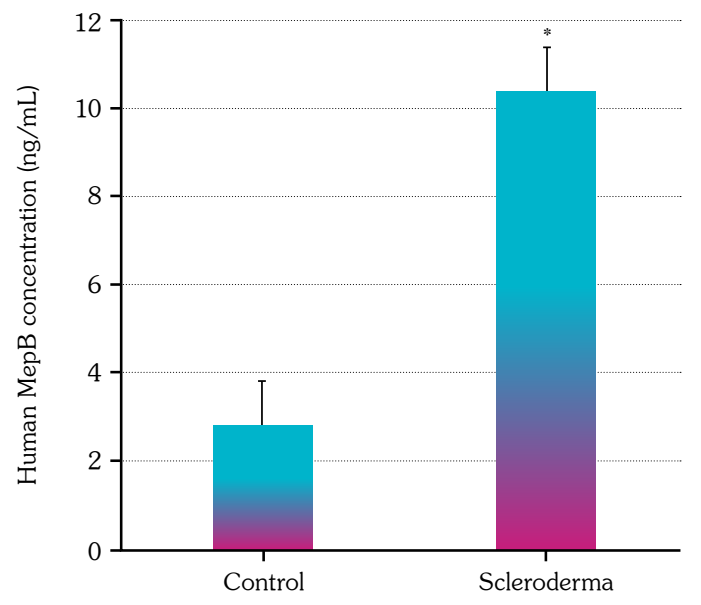

(b)

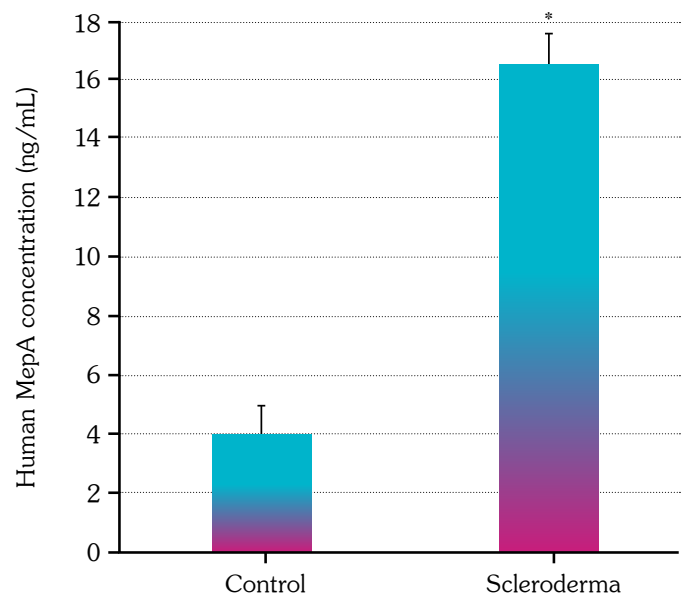

Figure 2. (a) Meprin-beta and (b) meprin-alpha concentration in SSc.

SSc: Scleroderma; * $\mathrm{p}<0.05$.
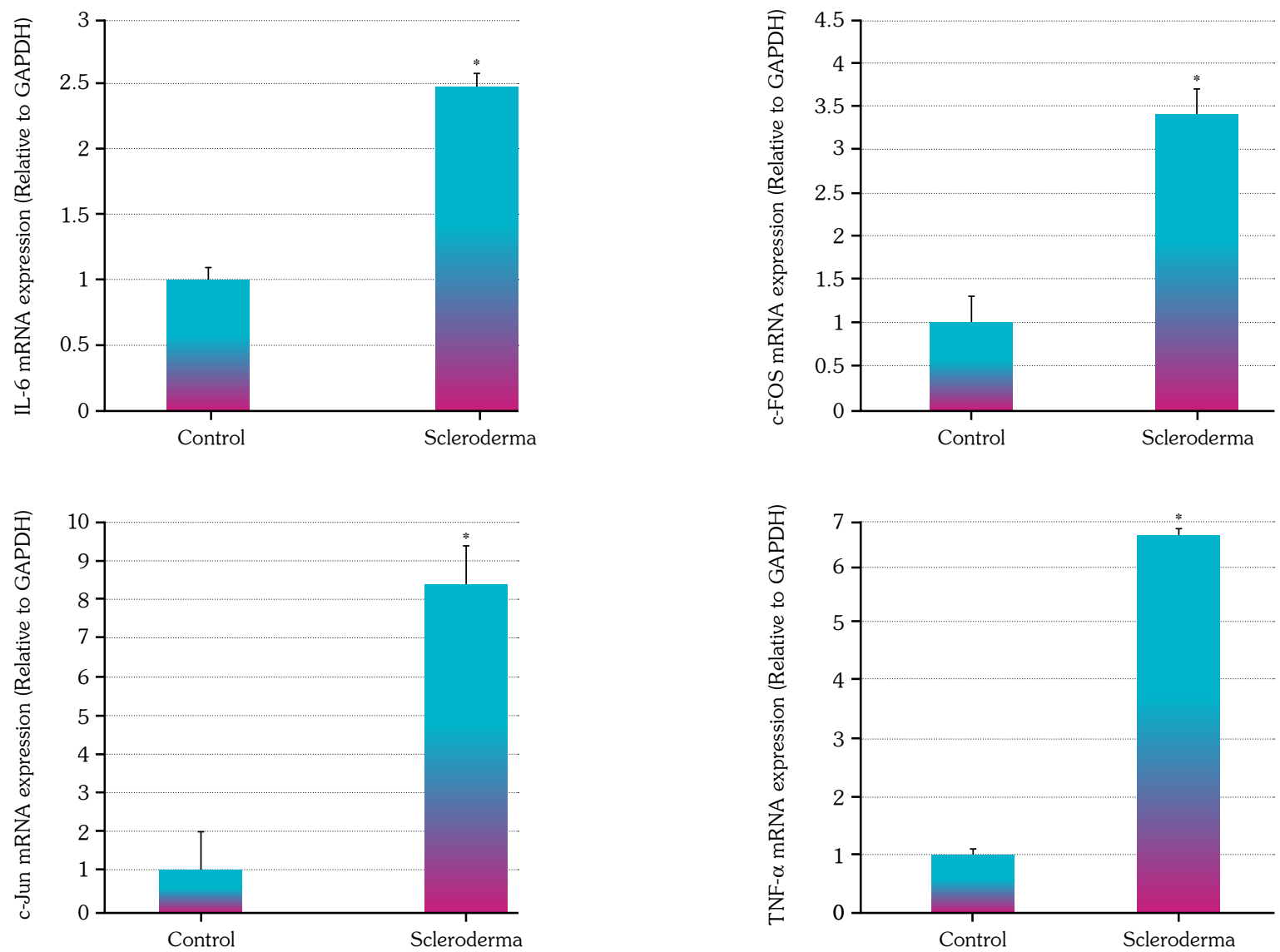

Figure 3. (a) IL-6, (b) c-Fos, (c) c-Jun, (d) TNF-alpha gene expressions in SSc.

IL-6: Interleukin; TNF- $\alpha$ : Tumor necrosis factor alpha; SSc: Scleroderma; * $\mathrm{p}<0.05$. 

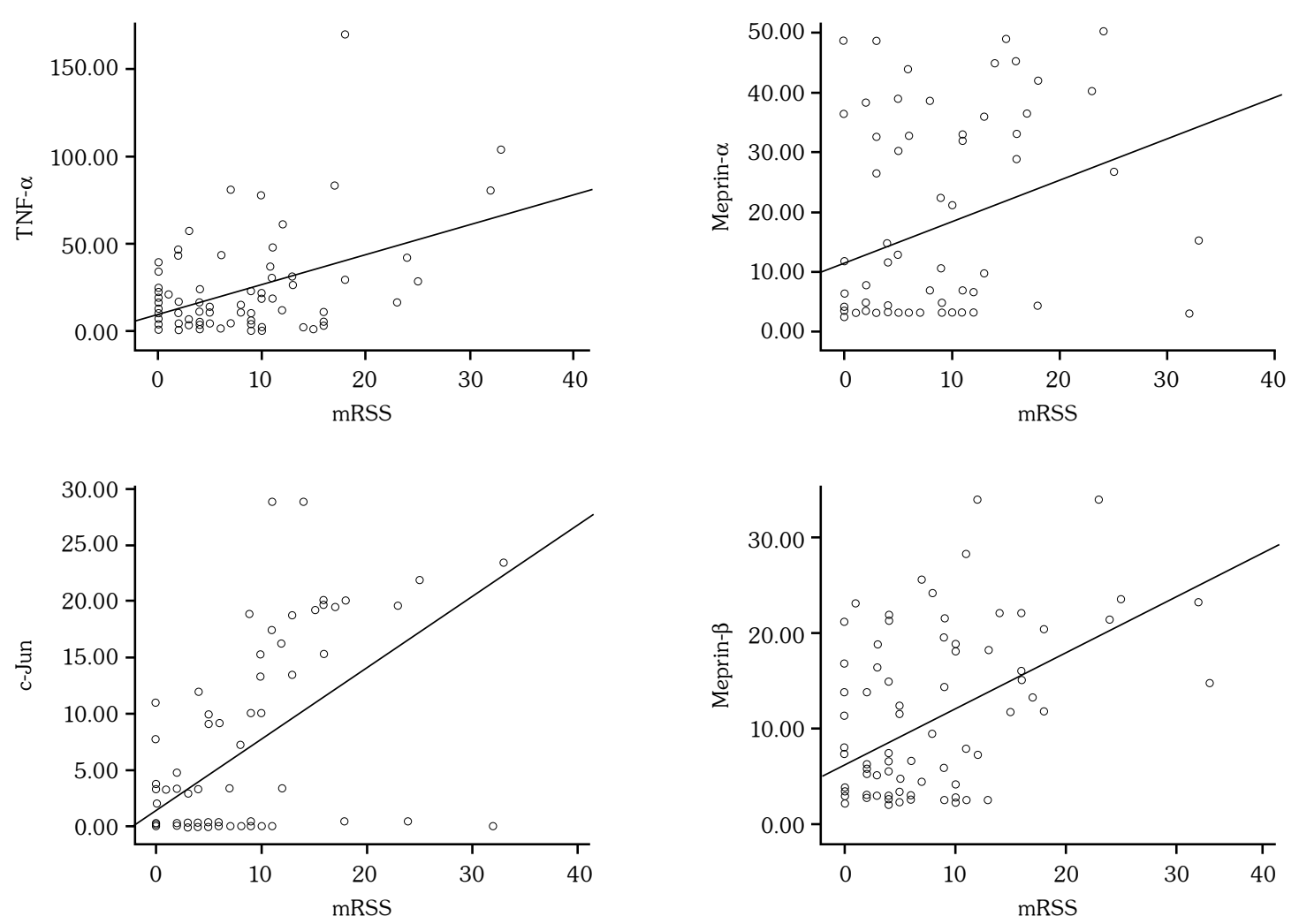

Figure 4. Positive correlations between TNF- $\alpha$ and mRSS, meprin-alpha and mRSS, c-Jun and mRSS, meprin-beta and mRSS.

TNF- $\alpha$ : Tumor necrosis factor alpha; mRSS: Modified Rodnan skin score.

\section{DISCUSSION}

Current SSc treatment options have limitations, and clinicians simply control symptoms without targeting the underlying pathophysiology. Further researches are needed to develop specific SSc treatments. The investigation of the molecular mechanisms underlying $\mathrm{SSc}$ has attracted considerable attention in recent years. ${ }^{20}$

In the present study, we investigated the meprin- $\alpha$ and meprin- $\beta$ protein levels and mRNA levels of related inflammatory molecules (IL-6, c-Fos, c-Jun, TNF- $\alpha$ ) in terms of their possible fibrotic effects. Our study results showed that meprin-alpha and meprin-beta play a role in SSc pathogenesis and inflammation.

Previous studies have shown increased levels of meprin metalloproteases in other fibrotic diseases characterized by pathological
ECM. ${ }^{21}$ Also, collagen maturation supported by meprin- $\alpha$ and meprin- $\beta$ is upregulated in ECMaccumulated diseases, such as keloids and fibrotic skin tumors. ${ }^{22}$ Meprins can break down and process many substrates, including basement membrane proteins, cytokines, cell adhesion proteins, hormones, bioactive peptides, and cell surface protein. ${ }^{6}$ Meprin- $\alpha$ expression is increased in a fibrotic skin disease, called keloid, and pulmonary hypertension characterized by the fibrotic condition of the lung. ${ }^{9,23}$ In a study in a mouse model of idiopathic pulmonary fibrosis, meprin- $\beta$ was shown to be upregulated. ${ }^{24}$ The same researchers found that, in meprin $\beta-\mathrm{KO}$ subjected to bleomycin-induced lung fibrosis, less collagen was accumulated than bleomycin-treated wild type mice. ${ }^{25}$ Review of the literature reveals that meprin- $\alpha$ and meprin- $\beta$ are new players for the processing and maturation of procollagens involved in the fibrosis. The present study is the first to assess the protein levels of meprin- $\alpha$ and 
meprin- $\beta$ in SSc. Based on our results, meprin- $\alpha$ and meprin- $\beta$ protein levels increased in the SSc group, compared to the controls. Therefore, we can speculate that meprins are related in SSc pathogenesis for fibrosis. These are new data for clinical applications of fibrosis-characterized diseases, such as SSc.

The AP-1 is a transcription factor that is a heterodimeric molecule composed of members of the Jun (c-Jun, jun B, junD) and Fos (c-Fos, fos B, Fra1, Fra-2). In their study, Avouac et al. ${ }^{12}$ showed that AP-1 was upregulated in a TGF-dependent manner in SSc. Also, AP-1 was found to be responsible for the transcriptional regulation of meprin- $\beta$. Meprin- $\beta$ is an important procollagen processing enzyme and plays a role in collagen deposition. ${ }^{8,9}$ Collagen deposition decreases in Mep1- $\alpha$ and Mep1- $\beta$ mice. ${ }^{8}$ Biasin et al. ${ }^{24}$ showed that transcriptional regulation of meprin $\beta$ by Fra2 in primary human smooth muscle cells to be regulated pro-fibrotic signaling via TGF- $\beta .{ }^{25}$

Meprin has been shown to degrade, induce, or inhibit several cytokines containing IL-1, IL-18, and IL-6, TNF- $\alpha .{ }^{24}$ The IL- 6 and TNF- $\alpha$ are inflammation markers for SSc. To the best of our knowledge, ILs and TNF- $\alpha$ work together. Meprin metalloproteases inactivate IL-6. ${ }^{26}$ The IL-6R is an important signal transducer. It can act via two mechanisms; one of them is classical signaling on the same cell and the other one is trans-signaling after proteolytic release acting on other cells that do not express the IL-6. A study showed that IL-6R was a shedding substrate of soluble meprin- $\alpha$ and meprin- $\beta$ membrane bound, resulting in bioactive soluble IL-6R. ${ }^{27}$ Soluble IL-6R is capable of inducing IL-6 transsignaling. ${ }^{27}$ Also, cleavage within the $\mathrm{N}$-terminal part of the IL-6R stalk region, distinct from the cleavage site, was reported for ADAM10/17. ${ }^{27}$ In our study, we observed that IL- 6 fold changes by qPCR and we found that meprin- $\alpha$, meprin- $\beta$, IL-6, and TNF- $\alpha$ were higher in the SSc patients than the control group. It probably depends on the SSc pathogenesis and these two types activate IL-6, thereby activating soluble IL-6 in ECM. Therefore, IL- 6 cleavage by meprins may control IL- 6 activity in vivo. Indeed, both meprin- $\alpha$ and $\beta$ were able to cleave IL- 6 into a smaller product, when incubated for a short time, but extensive degradation occurred upon prolonged incubation. ${ }^{24}$ Unlike the literature, our results showed that IL- 6 , TNF- $\alpha$, and mepris increased, probably depending on the SSc pathogenesis. In our results, TNF- $\alpha$ and mRSS showed a positive and significant correlation. Further researches are needed to investigate the link between meprins and inflammation markers.

The results of the present study showed that patients with SSc had a high gene expression of IL-6, c-Fos, c-Jun, and TNF- $\alpha$ with high meprin- $\alpha$, meprin- $\beta$ protein levels. More importantly, we found that increased gene expression levels of IL- 6 , c-Fos, c-Jun, and TNF- $\alpha$ and increased protein levels of meprin- $\alpha$, meprin- $\beta$ were correlated with the mRSS.

Taken together, autocrine TGF- $\beta$ signaling is one of the reasons for the fibroblast activation in SSc. ${ }^{28}$ This signaling leads to upregulated AP-1 levels in SSc. The c-Fos and c-Jun gene expression levels are related to AP-1. Overexpression of AP-1 may lead to the increased meprin levels. This pathology may be related to increased inflammation and collagen deposition in SSc. Also, the positive correlation with meprin levels and mRSS reveals the link between severity of the disease and the levels of meprin.

The main limitation of this study is that we were unable to evaluate SSc skin tissues for meprin- $\alpha$ and meprin- $\beta$.

In conclusion, our results confirm that the meprins are overexpressed in SSc. Meprins may be strong candidates being a part of SSc diagnosis, monitoring and, treatment; however, further studies are needed to confirm the underlying mechanism.

\section{Declaration of conflicting interests}

The authors declared no conflicts of interest with respect to the authorship and/or publication of this article.

\section{Funding}

This study was funded by Dokuz Eylül University Scientific Research Commission (2018.KB.SAG.050).

\section{REFERENCES}

1. Allanore Y, Simms R, Distler O, Trojanowska M, Pope $J$, Denton CP, et al. Systemic sclerosis. Nat Rev Dis Primers 2015;1:15002. 
2. Gabrielli A, Avvedimento EV, Krieg T. Scleroderma. N Engl J Med 2009;360:1989-2003.

3. Varga J, Trojanowska M, Kuwana M. Pathogenesis of systemic sclerosis: Recent insights of molecular and cellular mechanisms and therapeutic opportunities. J Scleroderma Relat Disord 2017;2:137-52.

4. Allanore Y, Dieude P, Boileau C. Genetic background of systemic sclerosis: Autoimmune genes take centre stage. Rheumatology (Oxford) 2010;49:203-10.

5. Kowal-Bielecka O, Fransen J, Avouac J, Becker M, Kulak A, Allanore Y, et al. Update of EULAR recommendations for the treatment of systemic sclerosis. Ann Rheum Dis 2017;76:1327-39.

6. Broder C, Becker-Pauly C. The metalloproteases meprin $\alpha$ and meprin $\beta$ : Unique enzymes in inflammation, neurodegeneration, cancer and fibrosis. Biochem J 2013;450:253-64.

7. Prox J, Arnold P, Becker-Pauly C. Meprin $\alpha$ and meprin $\beta$ : Procollagen proteinases in health and disease. Matrix Biol 2015;44-46:7-13.

8. Broder C, Arnold P, Vadon-Le Goff S, Konerding MA, Bahr K, Müller S, et al. Metalloproteases meprin $\alpha$ and meprin $\beta$ are $\mathrm{C}$ - and $\mathrm{N}$-procollagen proteinases important for collagen assembly and tensile strength. Proc Natl Acad Sci U S A 2013;110:14219-24.

9. Kronenberg D, Bruns BC, Moali C, Vadon-Le Goff S, Sterchi EE, Traupe H, et al. Processing of procollagen III by meprins: New players in extracellular matrix assembly? J Invest Dermatol 2010;130:2727-35.

10. Schütte A, Ermund A, Becker-Pauly C, Johansson ME, Rodriguez-Pineiro AM, Bäckhed F, et al. Microbial-induced meprin $\beta$ cleavage in MUC2 mucin and a functional CFTR channel are required to release anchored small intestinal mucus. Proc Natl Acad Sci U S A 2014;111:12396-401.

11. Schönherr C, Bien J, Isbert S, Wichert R, Prox J, Altmeppen $\mathrm{H}$, et al. Generation of aggregation prone $\mathrm{N}$-terminally truncated amyloid $\beta$ peptides by meprin $\beta$ depends on the sequence specificity at the cleavage site. Mol Neurodegener 2016;11:19.

12. Avouac J, Palumbo K, Tomcik M, Zerr P, Dees C, Horn $A$, et al. Inhibition of activator protein 1 signaling abrogates transforming growth factor $\beta$-mediated activation of fibroblasts and prevents experimental fibrosis. Arthritis Rheum 2012;64:1642-52.

13. Al-Shanti N, Saini A, Faulkner SH, Stewart CE. Beneficial synergistic interactions of TNF-alpha and IL-6 in C2 skeletal myoblasts--potential cross-talk with IGF system. Growth Factors 2008;26:61-73.

14. Lee J, Lee S, Zhang H, Hill MA, Zhang C, Park Y. Interaction of IL- 6 and TNF- $\alpha$ contributes to endothelial dysfunction in type 2 diabetic mouse hearts. PLoS One 2017;12:e0187189.
15. Rosenkranz S, Preston IR. Right heart catheterisation: Best practice and pitfalls in pulmonary hypertension. Eur Respir Rev 2015;24:642-52.

16. LeRoy EC, Black C, Fleischmajer R, Jablonska S, Krieg T, Medsger TA Jr, et al. Scleroderma (systemic sclerosis): Classification, subsets and pathogenesis. J Rheumatol 1988;15:202-5.

17. van den Hoogen F, Khanna D, Fransen J, Johnson SR, Baron M, Tyndall A, et al. 2013 classification criteria for systemic sclerosis: An American College of Rheumatology/European League against Rheumatism collaborative initiative. Arthritis Rheum 2013;65:2737-47.

18. Shi R, Chiang VL. Facile means for quantifying microRNA expression by real-time PCR. Biotechniques 2005;39:519-25.

19. Schmittgen TD, Livak KJ. Analyzing real-time PCR data by the comparative $\mathrm{C}(\mathrm{T})$ method. Nat Protoc 2008;3:1101-8.

20. Abraham DJ, Krieg T, Distler J, Distler O. Overview of pathogenesis of systemic sclerosis. Rheumatology (Oxford) 2009;48 Suppl 3:iii3-7.

21. Sage EH, Reed M, Funk SE, Truong T, Steadele M, Puolakkainen $\mathrm{P}$, et al. Cleavage of the matricellular protein SPARC by matrix metalloproteinase 3 produces polypeptides that influence angiogenesis. J Biol Chem 2003;278:37849-57.

22. Kruse MN, Becker C, Lottaz D, Köhler D, Yiallouros I, Krell HW, et al. Human meprin alpha and beta homooligomers: Cleavage of basement membrane proteins and sensitivity to metalloprotease inhibitors. Biochem J 2004;378:383-9.

23. Biasin V, Marsh LM, Egemnazarov B, Wilhelm $\mathrm{J}$, Ghanim B, Klepetko W, et al. Meprin $\beta$, a novel mediator of vascular remodelling underlying pulmonary hypertension. J Pathol 2014;233:7-17.

24. Biasin V, Wygrecka M, Marsh LM, Becker-Pauly C, Brcic L, Ghanim B, et al. Meprin $\beta$ contributes to collagen deposition in lung fibrosis. Sci Rep 2017;7:39969.

25. Kryczka J, Stasiak M, Dziki L, Mik M, Dziki A, Cierniewski C. Matrix metalloproteinase-2 cleavage of the $\beta 1$ integrin ectodomain facilitates colon cancer cell motility. J Biol Chem 2012;287:36556-66.

26. Keiffer TR, Bond JS. Meprin metalloproteases inactivate interleukin $6 . \mathrm{J}$ Biol Chem 2014;289:7580-8.

27. Arnold P, Boll I, Rothaug M, Schumacher N, Schmidt $\mathrm{F}$, Wichert R, et al. Meprin metalloproteases generate biologically active soluble interleukin- 6 receptor to induce trans-signaling. Sci Rep 2017;7:44053.

28. Ihn $\mathrm{H}$. Autocrine TGF-beta signaling in the pathogenesis of systemic sclerosis. J Dermatol Sci 2008;49:103-13. 